\title{
The effect of overtraining on serum leptin levels in women national wrestlers
}

\author{
Yamaner F. ${ }^{\mathrm{ABCDE}}$ \\ Department of Coaching Education, Faculty of Sport Sciences, Hitit University, Turkey
}

Authors' Contribution: A - Study design; B - Data collection; C - Statistical analysis; D - Manuscript preparation; E Funds collection.

\begin{abstract}
Purpose:

Weight control and weight loss during the periods of wrestling competitions are attached great importance -in order to be successful in wrestling. Leptin hormone level is known to play an important role in the control of body weight. For this reason, the purpose of this study was to investigate the effect of substantial weight loss on serum leptin levels of women wrestlers during competition periods.

Material: $\quad$ Twenty-five women wrestlers who trained for 2015 European Championship from Turkish National Wrestling Team and 26 sedentary women were recruited voluntarily for this study. Serum leptin levels of wrestlers in the experimental group and sedentary women in the control group were measured after overnight fasting before and after 21 days training camp of 2015 European Championship.

Results: $\quad$ Statistically significant difference was found in the direction of decrease in body weight, body mass index (BMI), glucose, insulin, cholesterol, triglyceride, LD, VLDL and leptin parameters and increase in HDL parameters before and after training camp in the experimental group $(p<.05)$. There was a statistically significant difference in leptin levels between the control group and women wrestlers $(p<.05)$. There was also a statistically significant difference in leptin levels of wrestlers before and after training camp $(p<.05)$.

Conclusions: $\quad$ As a result, the data obtained in the study indicate that intense wrestling trainings in camping period brought about weight loss and decreased leptin levels.

Keywords: wrestling, leptin, intense training, women.
\end{abstract}

\section{Introduction}

Being successful in wrestling depends on power, strength, sustainability in strength, muscle endurance at short periods, technical and tactical skills. Additionally, wrestling is characterized by short-lived and highintensity activities and requires significant anaerobic endurance [1]. A growing body of research suggests that leptin hormone has an effect on the control of body weight, regulation of food intake and increasing the energy usage $[2,3]$. Leptin is a well-known adipocyte mainly produced by white adipose tissue and is associated with fat mass, so plays an important role in regulating energy homeostasis and insulin sensitivity $[4,5,6]$.

Weight control and decline in body weight are also very important for success in [7]. Therefore, the investigation of leptin hormone is of great importance in competition period in which fast body weight changes are observed in wrestlers. Leptin, one of the adipokines [8], is abundantly synthesized and secreted by adipose tissue $[9,10]$. The main determiners of leptin level are body mass index (BMI) and body fat tissue [11, 12, 13]. Serum leptin levels are higher in women than in men when age and BMI are considered [12]. In this regard, the purpose of this study was to investigate the effect of substantial weight loss on serum leptin levels of women wrestlers during competition periods.

\section{Materials and Methods}

Participants

The study group compromised of 25 women wrestler

(c) Yamaner F., 2019

doi:10.15561/18189172.2019.0408 (experimental group), between 17-19 age range, who compete in free style and attended the last wrestlers' selection camp for 2015 Europe Championship and 26 sedentary women (control group) voluntarily.

\section{Research Design}

The experimental group had 21 days of training (3 weeks, 6 days a week, 2 hours a day) during the preparation camp. The last three days included tactical trainings with low intense. The control group, on the other hand, continued their normal daily life activities during this period. All participants confirmed that they did not eat, drink or use medication for 8 hours until their blood sample was taken. This study was conducted after taking the ethical report with the reference number 2010/09 and approved by Zonguldak Karaelmas University Medicine Faculty Research Hospital on 2nd September, 2010. All the participants of the study were informed about the details of the study approved by ethical committee.

\section{Data Collection}

Anthropometry and body composition

Data on the anthropometric characteristics of the study group, including age, body weight, height and BMI were obtained. The age and height values of the groups were taken once before the preparation camp and the remaining variables were taken twice before and after the training camp. Participants were measured using a metal rod with a precision of $\pm 0.1 \mathrm{~cm}$ and a body weight of $\pm 0,01 \mathrm{~kg}$ with a digital scale. The BMI values of the participants were calculated using the formula weight / height ${ }^{2}(\mathrm{~m})$.

In order to measure the skinfold thickness, a Holtain skinfold caliper was employed, applying $10 \mathrm{~g} / \mathrm{sq} \mathrm{mm}$ pressure at each angle. For this study, Durning and 
Womersley's Formula was utilised to calculate the body fat percentage of subjects with values from triceps, biceps, abdominal and suprailiak skinfold measurements [14].

The body fat percentage (BFP) calculations for women were made using the Durnin-Womersley Formula (1974), which can be shown as:

Body density

(D) $=1.1620-0.0630 \times \log X$;

$\log X=($ Biceps + Triceps + Subscapular + suprailiac $)$

Fat $\%=(4.95 / D)-4.5$

Blood analyses

Blood samples taken before and after the preparation camp of the study group were collected at Hitit University Biochemistry Laboratory. Samples were centrifuged at room temperature to coagulate and plasma samples were stored at $-80^{\circ} \mathrm{C}$ for biochemical analyzes. Diasource brand leptin elisa kit was employed for leptin analysis. Biochemical analyses were performed in accordance with the procedures in the Düzen Laboratory, found in Ankara, which has an international accreditation.

Statistical Analysis

The data obtained from the measurements were analyzed statistically using the SPSS 21.0 package program. According to the Shapiro-Wilcoxon normality test, Wilcoxon was used for variables with non-normal distributions before and after the preparation camp, whereas Mann-Whitney $U$ test and independent sample t-test were employed for comparison between the two groups. Statistically, $\mathrm{p}<.05$ values were considered significant.

\section{Results}

Based on the analysis in the study, it was found that the mean age and height of the experimental group were measured as $18.12 \pm 0.72$ years and $164.28 \pm 5.13 \mathrm{~cm}$, $18.85 \pm 1.04$ years and $162.73 \pm 5.86 \mathrm{~cm}$ for the control group, respectively. Body length, body weight, BMI and arithmetic means (M) and standard deviation (SD) values of the participants before and after the preparation camp are presented in Table 1.

When the data in Table 1 is analyzed, it can be seen that there is a statistically significant difference between wrestlers' weights before and after the preparation camp $(\mathrm{p}<.05)$. A statistically significant correlation was found when BMI values were compared $(\mathrm{p}<.01)$.

As shown in Table 2, it was found that there was a

Table 1. Anthropometric characteristics of the participants.

\begin{tabular}{lll}
\hline Variables & Experimental Group (n:25) & Control Group (n:26) \\
\hline & Before Camping & Before Camping \\
Body Weight $(\mathrm{kg})$ & $62.72 \pm 12.22$ & $57.88 \pm 5.61$ \\
Height $(\mathrm{cm})$ & $164.28 \pm 5.13$ & $162.73 \pm 5.86$ \\
BMI $\left(\mathrm{kg} / \mathrm{m}^{2}\right)$ & $23.17 \pm 3.94$ & $21.91 \pm 2.42$ \\
\hline
\end{tabular}

Table 2. In-group variable values before and after preparation camp (comparing Wilcoxon test conducted on in-group variables)

\begin{tabular}{|c|c|c|c|c|c|c|c|c|c|}
\hline \multirow{2}{*}{ Variables } & \multirow{2}{*}{$\begin{array}{l}\text { Camp } \\
\text { Period }\end{array}$} & \multicolumn{3}{|c|}{ Experimental Group ( $n=25)$} & \multirow[b]{2}{*}{$\mathbf{p}$} & \multicolumn{3}{|c|}{ Control Group $(n=26)$} & \multirow[b]{2}{*}{$\mathbf{p}$} \\
\hline & & Min. & Max & Mean \pm SD & & Min. & Max & Mean \pm SD & \\
\hline \multirow{2}{*}{ Glucose } & Before & 73 & 98 & $86.12 \pm 6.01$ & \multirow{2}{*}{$0.008^{*}$} & 73 & 98 & $85.04 \pm 6.33$ & \multirow{2}{*}{0.896} \\
\hline & After & 70 & 98 & $85.16 \pm 6.80$ & & 72 & 98 & $84.88 \pm 6.37$ & \\
\hline \multirow{2}{*}{ Insulin } & Before & 3.5 & 16.3 & $7.59 \pm 6.95$ & \multirow{2}{*}{$0.001^{*}$} & 2.8 & 41.4 & $8.33 \pm 7.51$ & \multirow{2}{*}{0.887} \\
\hline & After & 3.1 & 14.2 & $6.95 \pm 3.19$ & & 2.6 & 41.4 & $8.33 \pm 7.50$ & \\
\hline \multirow{2}{*}{ Cholesterol } & Before & 119 & 313 & $183.48 \pm 38.33$ & \multirow{2}{*}{$0.001 *$} & 128 & 236 & $175.15 \pm 27.18$ & \multirow{2}{*}{0.285} \\
\hline & After & 119 & 310 & $179.28 \pm 26.34$ & & 123 & 230 & $174.46 \pm 25.64$ & \\
\hline \multirow{2}{*}{ HDL } & Before & 30 & 85 & $62.76 \pm 15.30$ & \multirow{2}{*}{$0.001^{*}$} & 30 & 104 & $64.96 \pm 17.66$ & \multirow{2}{*}{0.262} \\
\hline & After & 32 & 88 & $65.84 \pm 15.68$ & & 32 & 105 & $63.23 \pm 17.29$ & \\
\hline \multirow{2}{*}{ LDL } & Before & 55.6 & 215.8 & $96.41 \pm 36.18$ & \multirow{2}{*}{$0.002 *$} & 49.0 & 141.6 & $90.15 \pm 24.66$ & \multirow{2}{*}{0.394} \\
\hline & After & 55.6 & 210.6 & $94.34 \pm 34.71$ & & 49.0 & 140 & $89.91 \pm 24.38$ & \\
\hline \multirow{2}{*}{ Triglycerides } & Before & 36 & 280 & $100.28 \pm 52.73$ & \multirow{2}{*}{$0.001 *$} & 30.0 & 284 & $106.42 \pm 60.10$ & \multirow{2}{*}{0.138} \\
\hline & After & 34 & 278 & $97.72 \pm 50.88$ & & 32.0 & 282 & $106.62 \pm 59.50$ & \\
\hline \multirow{2}{*}{ VLDL } & Before & 6.0 & 46.5 & $19.22 \pm 9.16$ & \multirow{2}{*}{$0.001^{*}$} & 6.0 & 56.8 & $20.86 \pm 12.42$ & \multirow{2}{*}{0.979} \\
\hline & After & 5.1 & 38.6 & $17.44 \pm 7.32$ & & 6.0 & 57.0 & $20.83 \pm 12.50$ & \\
\hline \multirow{2}{*}{ VYY } & Before & 14.8 & 20.4 & $17.30 \pm 15.48$ & \multirow{2}{*}{$0.001^{*}$} & 14.8 & 20.04 & $17.82 \pm 1.59$ & \multirow{2}{*}{0.179} \\
\hline & After & 12.4 & 17.5 & $15.48 \pm 1.30$ & & 14.8 & 20.04 & $17.89 \pm 1.63$ & \\
\hline \multirow{2}{*}{ Leptin } & Before & 1.0 & 18 & $4.70 \pm 2.95$ & \multirow{2}{*}{$0.001^{*}$} & 2.3 & 40 & $15.47 \pm 9.93$ & \multirow{2}{*}{0.230} \\
\hline & After & 1.0 & 10.3 & $2.95 \pm 1.95$ & & 2.3 & 40 & $15.45 \pm 9.74$ & \\
\hline
\end{tabular}

Note: $*$ p $<.05$ 
statistically significant difference in decrease of glucose and insulin, cholesterol, triglyceride, LDL, VLDL, leptin, VFM parameters and increase in HDL before and after camping of the experimental group. No difference was observed in the control group $(\mathrm{p}<.05)$.

As shown in the analyses in Table 3, Glucose, HDL and BFP values were normally distributed in groups, so independent t-test was employed and Mann Whitney U test was used for other parameters. No statistically significant difference was found between groups in terms of glucose, HDL and BFP averages before camping $(p>.05)$. There was no statistically significant difference between glucose and HDL averages between post - camp groups ( $p>.05)$. BFP was found to be significantly different between the groups $(\mathrm{p}<.001)$. The BFP average of the experimental group was found to be lower.

As shown in Table 4, there was no statistically significant difference between pre- and post-camp insulin, cholesterol, LDL triglyceride and VLDL values of the participants, except for Leptin $(p<.001)$. While the leptin levels of the experimental group decreased, those of the control group increased.

\section{Discussion}

This study has sought to investigate the effect of substantial weight loss on serum leptin levels of women wrestlers during competition periods, it was found that in elite wrestlers, loss of body weight is an important issue in every competition period in order to compete in the target weight category during professional sporting events. This cycle continues as weight loss and ongoing weight gain [15]. In line with the finding of this study, the article by Ziyagil et al. [16] conclude that the body weights of star wrestlers increase before and after the season with a statistical significant rate, $9,63 \%$. The works of Demirkan et al. [17] tell us that there were significant reductions

Table 3. Comparison of glucose, HDL and BFP values between the experimental group and control group before and after camping.

\begin{tabular}{|c|c|c|c|c|c|c|}
\hline \multirow{2}{*}{ Variables } & \multirow[b]{2}{*}{ Participants } & \multirow[b]{2}{*}{$\mathbf{N}$} & \multicolumn{2}{|l|}{ Before Camp } & \multicolumn{2}{|l|}{ After Camp } \\
\hline & & & Mean $\pm S D$ & $\mathbf{p}$ & Mean $\pm S D$ & $\mathbf{p}$ \\
\hline \multirow{2}{*}{ Glucose } & Wrestler & 25 & $86.12 \pm 6.01$ & 0.0535 & $85.16 \pm 6.80$ & 0,948 \\
\hline & Control & 26 & $85.04 \pm 6.33$ & & $84.88 \pm 6.37$ & \\
\hline \multirow{2}{*}{ HDL } & Wrestler & 25 & $62.76 \pm 15.30$ & 0.637 & $62.76 \pm 15.30$ & 0,852 \\
\hline & Control & 26 & $64.96 \pm 17.66$ & & $63.23 \pm 17.29$ & \\
\hline \multirow{2}{*}{ BFP } & Wrestler & 25 & $17.30 \pm 15.48$ & 0.244 & $15.48 \pm 1.30$ & $0.000 *$ \\
\hline & Control & 26 & $17.82 \pm 1.59$ & & $17.89 \pm 1.63$ & \\
\hline
\end{tabular}

Note: ${ }^{*} ; p<.05$

Table 4. Comparison of Insulin, Cholesterol, LDL, Triglyceride, VLDL, Leptin values before and after the camp (Mann Whitney $U$ test) in the experimental group and the control group

\begin{tabular}{|c|c|c|c|c|c|c|c|c|c|c|}
\hline \multirow{2}{*}{ Variables } & \multirow{2}{*}{ Participants } & \multirow[b]{2}{*}{ n } & \multicolumn{4}{|c|}{ Before Camp } & \multicolumn{4}{|c|}{ After Camp } \\
\hline & & & Min & Max. & Mean士SD & $\mathbf{p}$ & Min & Max & Mean $\pm S D$ & $\mathbf{p}$ \\
\hline \multirow{2}{*}{ Insulin } & Wrestler & 25 & 3.5 & 16.3 & $7.59 \pm 6.95$ & \multirow{2}{*}{0.880} & 3.1 & 14.2 & $6.95 \pm 3.19$ & \multirow{2}{*}{0.785} \\
\hline & Control & 26 & 2.8 & 41.4 & $8.33 \pm 7.51$ & & 2.6 & 41.4 & $8.33 \pm 7.50$ & \\
\hline \multirow{2}{*}{ Cholesterol } & Wrestler & 25 & 119 & 313 & $183.48 \pm 38.3$ & \multirow{2}{*}{0.355} & 119 & 310 & $179.28 \pm 26.34$ & \multirow{2}{*}{0.720} \\
\hline & Control & 26 & 128 & 236 & $175.15 \pm 27.2$ & & 123 & 230 & $174.46 \pm 25.64$ & \\
\hline \multirow[b]{2}{*}{ LDL } & Wrestler & 25 & 55.6 & 215.8 & $96.41 \pm 36.18$ & \multirow[b]{2}{*}{0.888} & 55.6 & 210.6 & $94.34 \pm 34.71$ & \multirow[b]{2}{*}{0.962} \\
\hline & Control & 26 & 49 & 141.6 & $90.15 \pm 24.66$ & & 49.0 & 140.0 & $89.91 \pm 24.38$ & \\
\hline \multirow{2}{*}{ Triglycerid } & Wrestler & 25 & 36 & 280 & $100.28 \pm 52.7$ & \multirow{2}{*}{0.699} & 34 & 278 & $97.72 \pm 50.88$ & \multirow{2}{*}{0.572} \\
\hline & Control & 26 & 30 & 284 & $106.42 \pm 60.1$ & & 32.0 & 282 & $106.62 \pm 59.50$ & \\
\hline \multirow{2}{*}{ VLDL } & Wrestler & 25 & 6.0 & 46.5 & $19.22 \pm 9.16$ & \multirow{2}{*}{0.880} & 5.1 & 38.6 & $17.44 \pm 7.32$ & \multirow{2}{*}{0.474} \\
\hline & Control & 26 & 6.0 & 56.8 & $20.86 \pm 12.42$ & & 6.0 & 57.0 & $20.83 \pm 12.50$ & \\
\hline \multirow{2}{*}{ Leptin } & Wrestler & 25 & 1.0 & 18.0 & $4.70 \pm 2.95$ & \multirow{2}{*}{$0.001^{*}$} & 1.0 & 10.3 & $2.95 \pm 1.95$ & \multirow{2}{*}{$0.001 *$} \\
\hline & Control & 26 & 1.0 & 10.3 & $2.95 \pm 1.95$ & & 2.3 & 40.0 & $15.45 \pm 9.74$ & \\
\hline
\end{tabular}

Note: ${ }^{*} ; p<.05$ 
in pre-and post-camp body weights of selected athletes in elite wrestlers. In this present study, the weight loss of the participants in the experimental group was $7.72 \%$ after the preparatory camp organized for 2015 European Championship, which can be considered as within normal limits and compatible with the related literature. It has been widely accepted that exercise regulates blood cholesterol and all other lipid metabolism in a positive way [18-21]. However, there are studies in the literature showing that exercise has no positive or significant effect on lipid parameters. Some studies on endurance and strength training have shown that there is an increase in HDL-C cholesterol and a decrease in LDL-C, TG values $[22,23]$, while there is no change in the literature [24].

According to the results obtained in the study, there was a statistically significant difference in decrease of glucose, insulin, cholesterol, triglyceride, LDL, VLDL parameters and increase in HDL parameters before and after camping of the test group ( $\mathrm{p}<0.05)$.

It was found that leptin levels of the experimental group were statistically different in leptin levels of control group $(\mathrm{p}<0.05)$ before the preparation camp. In some studies, higher leptin levels were found in women compared to men $[12,25]$. However, it was concluded that there was no significant difference between wrestling national team wrestlers $(n=45)$ and sedentary men $(n=$ 43) leptin levels [26]. In a similar study by Cicioğlu et al., pre-test and post-test measurements were conducted between wrestlers in a 25-day-old camp before an international tournament, and there was no statistically significant difference between leptin levels in the weightloss group of the test results [27]. In men, leptin levels begin to rise during childhood, peak at first adolescence, and then fall. For this reason, leptin levels in men are 3-4 times higher than men in this period [28]. In other words, this difference between the two study results can be attributed to the gender of the participants. According to these results, it can be noted that the leptin levels in the women who perform wrestling sports are significantly lower than the men who are engaged in wrestling sports.

\section{References}

1. Bompa TO, Carrera M. Periodization training for sports: science-based strength and conditioning plans for 17 sports. Champaign, IL: Human Kinetics; 2005.

2. Bouassida A, Chamari K, Zaouali M, Feki Y, Zbidi A, Tabka Z. Review on leptin and adiponectin responses and adaptations to acute and chronic exercise. Br J Sports Med. 201;:44:620-630. https://doi.org/10.1136/bjsm.2008.046151

3. Fantuzzi G, Faggioni R. Leptin in the regulation of immunity, inflammation, and Hematopoiesis. J Leukocyte Biol. 2000: 68:437-446.

4. Considine RV, Sinha MK, Heiman ML, Kriauciunas A, Stephens TW, Nyce MR, Ohannesian JP, Marco CC, McKee LJ, Bauer TL, Caro JF. Serum immunoreactive-leptin concentrations in normal-weight and obese humans. $N$ Engl J Med. 1996;334:292-295. https://doi.org/10.1056/NEJM199602013340503

5. Woods SC, D'Alessio DA. Central control of body weight
There was a statistically significant decrease in the leptin levels of the experimental group before and after the national team preparation camp $(\mathrm{p}<0.05)$. In elitelevel free style wrestlers, $4 \%$ fast weight loss programs significantly reduce the effects of certain hormones and leptin levels [29]. In another study Yanagawa et al. [6] compared 12-day pre-and post-camp body weight, fat mass and leptin values of university wrestlers and sedentary people and found that wrestlers had a significant decrease in leptin value, body weight and fat mass. It has been known that leptin concentrations in circulation are related to fat mass [4].

\section{Conclusion}

In this study, it can be said that the decrease in fat mass and serum leptin concentrations of wrestlers may be associated with decreased body fat content. It can also be said that the intensive preparatory program and accordingly the rapid weight loss caused a significant decrease in the leptin level of the subject group. In a nutshell, during the preparation camp period, intensive exercise program caused rapid weight loss and it was determined that serum leptin level decreased significantly in wrestling women.

\section{Highlights}

- There was a statistically significant decrease in the leptin levels of the women wrestlers before and after the national wrestling team preparation camp.

- The leptin levels of women wrestlers were statistically different in leptin levels of sedentary women.

- There were statistically significant differences in blood parameters of women wrestlers in before and after camping period.

\section{Acknowledgment}

We gratefully acknowledge the help of all the participant who took part in the study.

\section{Conflict of interests}

The authors state that there is no conflict of interest. and appetite. J Clin Endocrinol Metab. 2008; 93:37-50. https://doi.org/10.1210/jc.2008-1630

6. Yanagawa Y, Morimura T, Tsunekawa K, Seki, K, Ogiwara T, Kotajima N, Machida T, Matsumoto S, Adachi T, Murakami M. Oxidative stress associated with rapid weight reduction decreases circulating adiponectin concentrations. Endocrine Journal. 2010;57(4):339-345. https://doi.org/10.1507/endocrj.K09E-359

7. Oppliger RA, Case HS, Horswill CA, Landry GL, Shelter AC. American College of Sports Medicine position stand. Weight loss in wrestlers. Medicine and Science in Sports and Exercise. 1996;28(6):9-12. https://doi.org/10.1097/00005768-199610000-00049

8. Kondo T, Kobayashi I, Murakami M. Effect of exercise on circulating adipokine levels in obese young women. Endocr J. 2006;53:189-195. https://doi.org/10.1507/endocrj.53.189

9. Gordon ME, Mckeever KH, Bokman S, Betros CL, Manso- 
Filho H, Liburt N, Streltsova J. Interval exercise alters feed intake as well as leptin and ghrelin concentrations in standardbred mares. Equine Vet J. 2006;36(suppl):596-605. https://doi.org/10.1111/j.2042-3306.2006.tb05611.x

10.Guerra B, Santana A, Fuentes T, Delgado-Guerra S, CabreraSocorro A, Dorado C, Calbet JAL. Leptin receptors in human skeletal muscle. J Appl Physiol. 2007;102:1786-1792. https://doi.org/10.1152/japplphysiol.01313.2006

11.Kilpeläinen TO, Carli JFM, Skowronski AA, Sun Q, Kriebel J, Feitosa MF et al. Genome-wide metaanalysis uncovers novel loci influencing circulating leptin levels. Nature Communications. 2016;7(1): 10494. https://doi.org/10.1038/ncomms10494

12.Nia FR, Hojjati Z, Rahnama N, Soltani B. Leptin, heart disease and exercise. World Journal of Sport Sciences. 2009;2(1):13-20.

13.Perusse L, Collier G, Gagnon J, Leon AS, Rao DC, Skinner JS et al. Acute and chronic effects of exercise on leptin levels in Humans. J Appl Physiol. 1997;83:5-10. https://doi.org/10.1152/jappl.1997.83.1.5

14.Durning JVGA, Womersley J. Body fat assessed from total body density and its estimation from skinfold thicknessmeasurements on 481 men and women aged from 16 to 72 years. British Journal of Nutrition. 1974;32(1):77-97. https://doi.org/10.1079/BJN19740060

15.Cutter G, St Jeor S, Brunner R, Wolfe P, Foreyt J, Dyer A, Brownell KD. Methodological issues in weight cycling. Ann Behav Med Publ Soc Behav Med. 1996;18:280-289. https://doi.org/10.1007/BF02895290

16.Ziyagil MA, Zorba E, Kutlu M, Tamer K, Torun K. Effects of yearly training on body composition and physiological properties of Turkish national free-style cadet wrestlers. G.Ü. Beden Eğitimi ve Spor Bilimleri Dergisi.1996;1(4):9-16.

17.Demirkan E, Kutlu M, Koz M, Ünver R, Bulut E. Elit güreşçilerde vücut kompozisyonu ve hidrasyon değişimlerinin incelenmesi. Selçuk Üniversitesi Beden Eğitimi ve Spor Bilim Dergisi. 2012;14(2):179-183.

18.Shiraev T, Barclay G. Evidence based exercise. Australian Family Physician. 2012;41(12):960-962.

19. Volodchenko OA, Podrigalo LV, Iermakov SS, Zychowska MT, Jagiello W. The Usefulness of Performing Biochemical Tests in the Saliva of Kickboxing Athletes in the Dynamic of Training. Biomed Research International. 2019;2019:7. https://doi.org/10.1155/2019/2014347
20.Antosiewicz J, Kortas J, Tomczyk M, Prusik K, Prusik $\mathrm{K}$, Jaworska $\mathrm{J}$, et al. Exercise induced-increase in blood hepcidin is the same in wt and heterozygotes for HFE H63D. American Journal of Hematology. 2017;92(8):E479-E479.

21.Prusik K, Kortas J, Prusik K, Mieszkowski J, Jaworska J, Skrobot W, et al. Nordic Walking Training Causes a Decrease in Blood Cholesterol in Elderly Women Supplemented with Vitamin D. Frontiers in Endocrinology. 2018;9. https://doi.org/10.3389/fendo.2018.00042

22.Boardley D, Fahlman M, Topp R, Morgan AL, McNevin N. The impact of exercise training on blood lipids in older adults. The American Journal of Geriatric Cardiology. 2007;16(1):30-35. https://doi.org/10.1111/j.1076-7460.2007.05353.x

23.Leon AS, Sanchez OA. Response of blood lipids to exercise training alone or combined with dietary intervention. Medicine and Science in Sports and Exercise. 2001;33(6):502-515. https://doi.org/10.1097/00005768-200106001-00021

24.Stefanick ML, Mackey S, Sheehan M, Ellsworth N, Haskell WL, Wood PD. Effects of diet and exercise in men and postmenopausal women with low levels of HDL cholesterol and high levels of LDL cholesterol. New England Journal of Medicine, 1998;339(1):12-20. https://doi.org/10.1056/NEJM199807023390103

25.Aslan K Serdar Z, Tokullugil HA. Multifuntionel hormone: Leptin. Uludăg Üniversitesi Tıp Fakültesi Dergisi. 2004;30(2):113-118.

26.Yamaner F, Bayraktaroğlu T, Atmaca H, Ziyagil MA, Tamer K. Serum Leptin, lipoprotein levels, and glucose homeostasis between national wrestlers and sedentary males. Turk J Med Sci. 2010;40(3):471-477.

27.Cicioğlu HI, Işık O, Yıldırım I, Ünveren A, Karagöz S. The effects of dehydration before competition upon body compositions, leptin hormone and ghrelin hormone among elite wrestlers. Biomedical Research. 2017;28(10):43354341.

28.Baltacı AK, Moğulkoç RA, Öztürk A. Testosterone and zinc supplementation in castrated rats: Effects on plasma leptin levels and relation with LH, FSH and testosterone. Life Sciences. 2006;78:746-752. https://doi.org/10.1016/j.lfs.2005.05.098

29.Talaei M, Nazem F, Ranjbar K. The impact of rapid weight loss $(4 \%)$ on leptin, adiponectin, and insulin resistance in elite adult free style wrestlers. $J$ Sports Med Phys Fitness. 2017;57(4):434-440.

\section{Information about the author:}

Yamaner F.; http://orcid.org/0000-0002-2302-8650; farukyamaner@hitit.edu.tr; Department of Coaching Education, Faculty of Sport Sciences, Hitit University; Hitit Üniversitesi Spor Bilimleri Fakültesi, Çorum/Turkey.

Cite this article as:

Yamaner F. The effect of overtraining on serum leptin levels in women national wrestlers. Pedagogics, psychology, medicalbiological problems of physical training and sports, 2019;23(4):209-213. https://doi.org/10.15561/18189172.2019.0408

This is an Open Access article distributed under the terms of the Creative Commons Attribution License, which permits unrestricted use, distribution, and reproduction in any medium, provided the original work is properly cited (http://creativecommons.org/licenses/by/4.0/deed.en).

Received: 28.04.2019

Accepted: 28.05.2019; Published: 29.08.2019 